\title{
Bacterial induction of autoantibodies to $\beta 2$-glycoprotein-I accounts for the infectious etiology of antiphospholipid syndrome
}

\author{
Miri Blank, ${ }^{1}$ Ilan Krause, ${ }^{1}$ Mati Fridkin, ${ }^{2}$ Nathan Keller, ${ }^{3}$ Juri Kopolovic, ${ }^{4}$ Iris Goldberg, ${ }^{4}$ \\ Ana Tobar, ${ }^{5}$ and Yehuda Shoenfeld ${ }^{1}$ \\ ${ }^{1}$ Center for Autoimmune Diseases, Department of Internal Medicine B, Sheba Medical Center, Tel-Hashomer, \\ Sackler Faculty of Medicine, Tel-Aviv University, Tel-Aviv, Israel \\ ${ }^{2}$ Department of Organic Chemistry, The Weizmann Institute of Science, Rehovot, Israel \\ ${ }^{3}$ Department of Clinical Microbiology, \\ ${ }^{4}$ Department of Pathology, Sheba Medical Center, Tel-Hashomer, and \\ ${ }^{5}$ Department of Pathology, Rabin Medical Center, Tel-Hashomer, Sackler Faculty of Medicine, Tel-Aviv University, \\ Tel-Aviv, Israel
}

Address correspondence to: Yehuda Shoenfeld, Department of Medicine B, Sheba Medical Center, Tel-Hashomer 52621, Israel. Phone: 972-3-5302652; Fax: 972-3-5352855; E-mail: Shoenfel@post.tau.ac.il.

Received for publication January 24, 2001, and accepted in revised form January 28, 2002.

\begin{abstract}
The antiphospholipid syndrome (APS) is characterized by the presence of pathogenic autoantibodies against $\beta 2$-glycoprotein-I ( $\beta 2 \mathrm{GPI}$ ). The factors causing production of anti- $\beta 2 \mathrm{GPI}$ remain unidentified, but an association with infectious agents has been reported. Recently, we identified a hexapeptide (TLRVYK) that is recognized specifically by a pathogenic anti- $\beta 2 \mathrm{GPI} \mathrm{mAb}$. In the present study we evaluated the APS-related pathogenic potential of microbial pathogens carrying sequences related to this hexapeptide. Mice immunized with a panel of microbial preparations were studied for the development of anti- $\beta 2$ GPI autoantibodies. IgG specific to the TLRVYK peptide were affinity purified from the immunized mice and passively infused intravenously into naive mice at day 0 of pregnancy. APS parameters were evaluated in the infused mice on day 15 of pregnancy. Following immunization, high titers of antipeptide [TLRVYK] anti- $\beta 2$ GPI Ab's were observed in mice immunized with Haemophilus influenzae, Neisseria gonorrhoeae, or tetanus toxoid. The specificity of binding to the corresponding target molecules was confirmed by competition and immunoblot assays. Naive mice infused with the affinity-purified antipeptide Ab's had significant thrombocytopenia, prolonged activated partial thromboplastin time and elevated percentage of fetal loss, similar to a control group of mice immunized with a pathogenic anti-ß2GPI mAb. Our study establishes a mechanism of molecular mimicry in experimental APS, demonstrating that bacterial peptides homologous with $\beta 2 \mathrm{GPI}$ induce pathogenic anti- $\beta 2 \mathrm{GPI}$ Ab's along with APS manifestations.
\end{abstract}

J. Clin. Invest. 109:797-804 (2002). DOI:10.1172/JCI200212337.

\section{Introduction}

The antiphospholipid syndrome (APS) is characterized by a wide variety of hemocytopenic and vaso-occlusive manifestations and recurrent fetal loss associated with autoantibodies directed against negatively charged phospholipids (aPLs), mainly anticardiolipin (aCL) $A b$ 's (1). In the last decade, $\beta 2$-glycoprotein-I ( $\beta 2 \mathrm{GPI}$ ) has become a subject of increasing interest because it was described as the actual target antigen for autoimmune aPLs (2-4). The pathogenicity of anti- 32 GPI $\mathrm{Ab}$ 's was demonstrated in naive mice and rabbits $(5,6)$. It has been postulated that anti- $\beta 2$ GPI Ab's exert a direct pathogenic effect by interfering with homeostatic reactions occurring on the surface of platelets or vascular endothelial cells as well as the placenta (7). The factor or factors causing production of aPL$\beta 2 G P I$ in APS remains unidentified. Several indirect arguments support the idea that microbial agents might influence the course of APS, and an association between APS and several microbial pathogens has been documented recently (8-13). Microbial agents or viruses can induce autoimmune diseases by a variety of mechanisms (14-16). For example, proteins of certain infectious agents can act as polyclonal activators on unique lymphocyte subsets. Viruses can preferentially infect/destroy a particular $\mathrm{T}$ cell subset, leading to an imbalance in the immune response. In other instances, infectious agents can upregulate Th 1 cytokines, thereby increasing selected expression of molecules such as MHC glycoproteins, as well as activation of costimulatory molecules. Several microbial agents have been found to encode superantigens that can selectively activate subset(s) of T cells. Microbes can also direct the release of cytokines and chemokines, which can act as growth, differentiation, or chemotactic fac-tors for different Th populations and regulate expression of MHC class I and class II molecules (14-16). Lastly, microbes can contain chemical structures that mimic 
normal host self-proteins, a phenomenon termed molecular mimicry. Antigenic similarity of either molecule's linear amino acid sequences or the conformational structure between antigens of infectious agents and host tissues might trigger an immune response against the shared determinant. As a result, the tolerance to autoantigens breaks down, and the pathogenspecific immune response that is generated crossreacts with host structures to cause tissue damage and disease. A role for molecular mimicry in the pathogenesis of autoimmune diseases such as allergic encephalomyelitis, experimental myocarditis, experimental autoimmune uveitis, and keratitis (17-24) has been shown recently in several animal models.

Previously, using a hexapeptide phage display library, we identified a hexapeptide (TLRVYK) that is specifically recognized by a pathogenic anti- $\beta 2$ GPI $m A b$ named $\mathrm{H}-3$, which causes endothelial cell activation and induces experimental APS $(25,26)$. The TLRVYK peptide specifically inhibited, both in vitro and in vivo, the biological functions of the H-3 anti- $\beta 2$ GPI mAb (25). Employing the Swiss Protein Database, we found a high homology between the TLRVYK hexapeptide and peptidic domain of various bacteria and viruses (Table 1). Therefore, in the present study we sought to evaluate the pathogenic potential of these epitopemimicking microbial pathogens regarding both serological and clinical features of APS.

\section{Methods}

Preparation of bacterial extracts. Bacterial particles were prepared from Haemophilus influenzae, Streptococcus pneumoniae, Shigella dysenteriae, Neisseria gonorrhoeae, Klebsiella pneumoniae, Escherichia coli, Proteus mirabilis, tetanus toxoid, and the yeast Candida albicans. The bacteria were washed with PBS, resuspended in lysed buffer ( $10 \mathrm{mM}$ Tris, $\mathrm{pH}$ 7.6, 15 $\mathrm{mM} \mathrm{NaCl}, 1 \%$ Triton X-100, $10 \mathrm{mM}$ EDTA) supplemented with protease inhibitor cocktail (Roche Molecular Biochemicals $\mathrm{GmbH}$, Mannheim, Germany), and incubated 20 minutes at $4^{\circ} \mathrm{C}$. The cell-free supernatants were recovered by centrifugation of the suspensions at $14,000 \mathrm{cpm}$ for 15 minutes at $4^{\circ} \mathrm{C}$. Bacterial DNA and RNA were digested by incubating the supernatants with RNase (1 $\mathrm{mg} / \mathrm{ml})$ and DNase $(1 \mathrm{mg} / \mathrm{ml})$ at $37^{\circ} \mathrm{C}$ for 1 hour, sequentially. The protein concentration of the extracts was determined by the Lowry method (Bio-Rad Laboratories Inc., Richmond, California, USA).

The synthetic peptides used in the study. The synthetic peptide CATLRVYKGG, which binds specifically to the $\mathrm{H}-3 \mathrm{mAb}\left(\mathrm{IC}_{50} 10^{-8}\right)(25)$, was used; the same peptide was used in a scrambled form (TGVGKALYCR) as a negative control. (Bold letters indicate the original hexapeptide.) The peptides were prepared by conventional solid-phase peptide synthesis, using an ABIMED AMS-422 automated solid-phase multiple peptide synthesizer (AVIMED GmbH, Langfeld, Germany). For determination of purity, analytical reverse-phase HPLC was performed using a prepacked-100 RP-18 column (Merck KGaA, Darmstadt, Germany) (25).
Immunization of mice. Naive BALB/c mice were immunized intradermally with a microbial particle (10 $\mu \mathrm{g} /$ mouse) in CFA and boosted intradermally with the microbial particles in PBS 3 weeks later. For extensive $\mathrm{Ab}$ production, a subgroup of mice was subjected weekly intraperitoneally with a microbial particle (50 $\mu \mathrm{g} /$ mouse) in CFA followed by two intraperitoneal booster injections in CFA. The mice were immunized with a microbial pathogen homologous with the TLRVYK hexapeptide (Table 1) and with K. pneumoniae, E. coli, and P. mirabilis as negative controls. In addition, since the H-3 anti- $\beta 2$ GPI mAb was originally generated from peripheral blood lymphocytes of a healthy subject immunized with diphtheria and tetanus (27), an additional group of mice was immunized with tetanus toxoid. The mice were bled every 2 weeks after boost injection, and the presence of mouse aCL, anti- $32 \mathrm{GPI}$, antipeptide(CATLRVYKGG), anti-scrambled peptide(TGVGKALYCR), antiphosphatidylcholine, and anti-dsDNA autoantibodies were determined by ELISA.

Detection of antiphospholipid and anti- $\beta 2$ GPI Ab's. The levels of antiphospholipid Ab's in the sera of the immunized mice, were detected by ELISA. Ninety-six-well ELISA plates (NUNC A/C, Roskilde, Denmark) were coated with $50 \mu \mathrm{g} / \mathrm{ml}$ cardiolipin or phospholipid (Sigma Chemical Co., St. Louis, Missouri, USA) in ethanol or $\beta 2 \mathrm{GPI}(10 \mu \mathrm{g} / \mathrm{ml})$ in PBS. Following blocking with $3 \%$ BSA, mice sera were added at different dilutions and incubated for 2 hours at room temperature. Bound mice Ab's were detected using goat anti-mouse IgG conjugated to alkaline phosphatase (Sigma Chemical Co.) and appropriate substrate. The color reaction was read in Titertrek ELISA reader (SLT Labinstruments GmbH, Salzburg, Austria) at OD of $405 \mathrm{~nm}$. Extensive washing with PBS followed each step.

Detection of anti-dsDNA Ab's. Anti-dsDNA Ab's were detected as follows: polystyrene plates (96-well; Nunc $\mathrm{A} / \mathrm{S}$ ) were coated sequentially with poly-L-lysine (50 $\mu \mathrm{g} / \mathrm{ml}$ in water $)$, calf thymus dsDNA $(2.5 \mu \mathrm{g} / \mathrm{ml}$ in TBS, treated with S1 nuclease in nuclease buffer at $37^{\circ} \mathrm{C}$ ), and poly-L-glutamate $(50 \mu \mathrm{g} / \mathrm{ml})$. Washing between steps was performed using TBS with $0.05 \%$ Tween- 20 . Following blocking with $3 \%$ BSA, mice sera at different concentrations were added for 2-hour incubation at room temperature. The binding was detected as described for antiphospholipid Ab's.

ELISA to detect antipeptide Ab binding. Streptavidincoated plates were incubated with biotinylated peptides (CATLRVYKGG and the scrambled peptide TGVGKALYCR) and blocked with 3\% BSA. Mouse sera or affinity-purified mouse antipeptide CATLRVYKGG Ab's were added at different concentrations. The binding was detected by anti-mouse IgG conjugated to alkaline phosphatase followed by the addition of appropriate substrate.

Peptide biotinylation. Eleven milligrams of resin-bound peptides (Wang-Resin; Calbiochem-Novabiochem AG, Lufelfingen, Switzerland) was suspended in $\mathrm{N}$-methyl-2pyroidone, and $15 \mathrm{mmol}$ of biotin- $N$-hydroxysuccinimide 
(Sigma Chemical Co.), and $15 \mathrm{nmol}$ of di-isopropylethylamine was added to the peptide mixture. After 16 hours, the biotinylated peptides were no longer protected and were cleaved from the resin by a cleavage mixture containing 5\% triethylsilan (Fluka Chemie $\mathrm{GmbH}$, Buchs, Switzerland), $5 \%$ water, and $90 \%$ trifluoroacetic acid (TFA). The cleaved peptides were precipitated with icecold peroxide-free ether, and the pellet was dissolved in water and subsequently lyophilized. Biotinylated peptides were purified by HPLC using prepacked LiChroCart RP-18 column $(250 \times 10 \mathrm{~mm}$; Merck KGaA), employing a binary gradient formed from $0.1 \%$ TFA in $\mathrm{H}_{2} \mathrm{O}$ and $0.1 \%$ TFA in $15 \%$ acetonitrile in $\mathrm{H}_{2} \mathrm{O}$.

Fractionation of mouse Ab's on affinity peptide column. CATLRVYKGG affinity peptide column was prepared by adding thiol containing peptide to MBPH [4-(4NMaleimidophenil)-butyric acid hydrazide-HCl] (22305; Pierce Chemical Co., Rockford, Illinois, USA) and coupling the peptide adduct with $\mathrm{CNBr}$-activated Sepharose-4B (17-0430-01; Pharmacia Biotech AB, Uppsala, Sweden), according to the manufacturer's instructions. Mouse sera, isolated from the different groups of the bacteria-immunized mice, were loaded onto the peptide column. Following washing with PBS, the bound $\mathrm{Ab}$ 's were eluted with glycine- $\mathrm{HCl} 0.2 \mathrm{M}, \mathrm{pH}$ 2.2. The $\mathrm{pH}$ was neutralized with Tris $(2 \mathrm{M})$, and the samples were dialyzed against PBS.

The specificity of the binding of the purified mouse antipeptide Ab's was confirmed by an immunoblot study. Microbial particles were loaded on $12 \%$ SDS PAGE in nonreduced condition and transferred to nitrocellulose (NC) paper. Following blocking of the $\mathrm{NC}$ with $3 \% \mathrm{BSA}\left(1\right.$ hour at $\left.37^{\circ} \mathrm{C}\right)$, the $\mathrm{NC}$ samples were incubated with sera (1:100) and isolated from bacteria- immunized mice before loading on peptide column or with the isolated fractions $(20 \mu \mathrm{g} / \mathrm{ml}) 4$ hours at room temperature. The binding was probed with anti-mouse IgG peroxidase, and appropriate substrate was added. Competition assays. The affinity-purified antipeptide $A b$ 's, derived from mice immunized with the various microbial pathogens at $50 \%$ of the maximal binding activity to the TLRVYK peptide, were preincubated with varying concentrations $(0-100 \mu \mathrm{g} / \mathrm{ml})$ of the studied peptide, or with the same peptide in its scrambled form, overnight at $4^{\circ} \mathrm{C}$. The mixture was added to ELISA plates and precoated with streptavidin and the biotinylated TLRVYK peptide. The remaining activity was measured as detailed above, using an anti-mouse Fc fragment conjugated with alkaline phosphatase. The percentage of inhibition was calculated as follows: $\%$ inhibition = [(OD control - OD with competitor)/OD control $] \times 100$.

Determination of $A b$ affinity. The affinity of mouse antipeptide $A b$ 's derived from the different groups of the immunized mice were tested for affinity to $\beta_{2}$ GPI on $\beta_{2}$ GPI-coated plates blocked with 3\% BSA. The concentration of the immunoglobulin was $10 \mu \mathrm{g} / \mathrm{ml}$. The affinity index, which is the molar concentration of $\mathrm{NH}_{4} \mathrm{SCN}$ required to reduce the initial OD by $50 \%$, was determined.

Three-dimensional presentation of $\beta_{2}$ GPI and tetanus toxoid. Three-dimensional Ribbon diagram of the $\beta_{2}$ GPI and partial structure of tetanus toxoid were produced using the program Insight II (MSI Inc., San Diego, California, USA).

Induction of experimental APS by passive transfer. Mouse IgG specific to the relevant peptide, affinity purified from mice immunized with tetanus, $H$. influenzae, Streptococcus pneumoniae, Shigella dysenteriae, N. gonorrhoeae, or K. pneumoniae (negative control), were used

Table 1

Homology between the TLRVYK peptide and various microbial pathogens

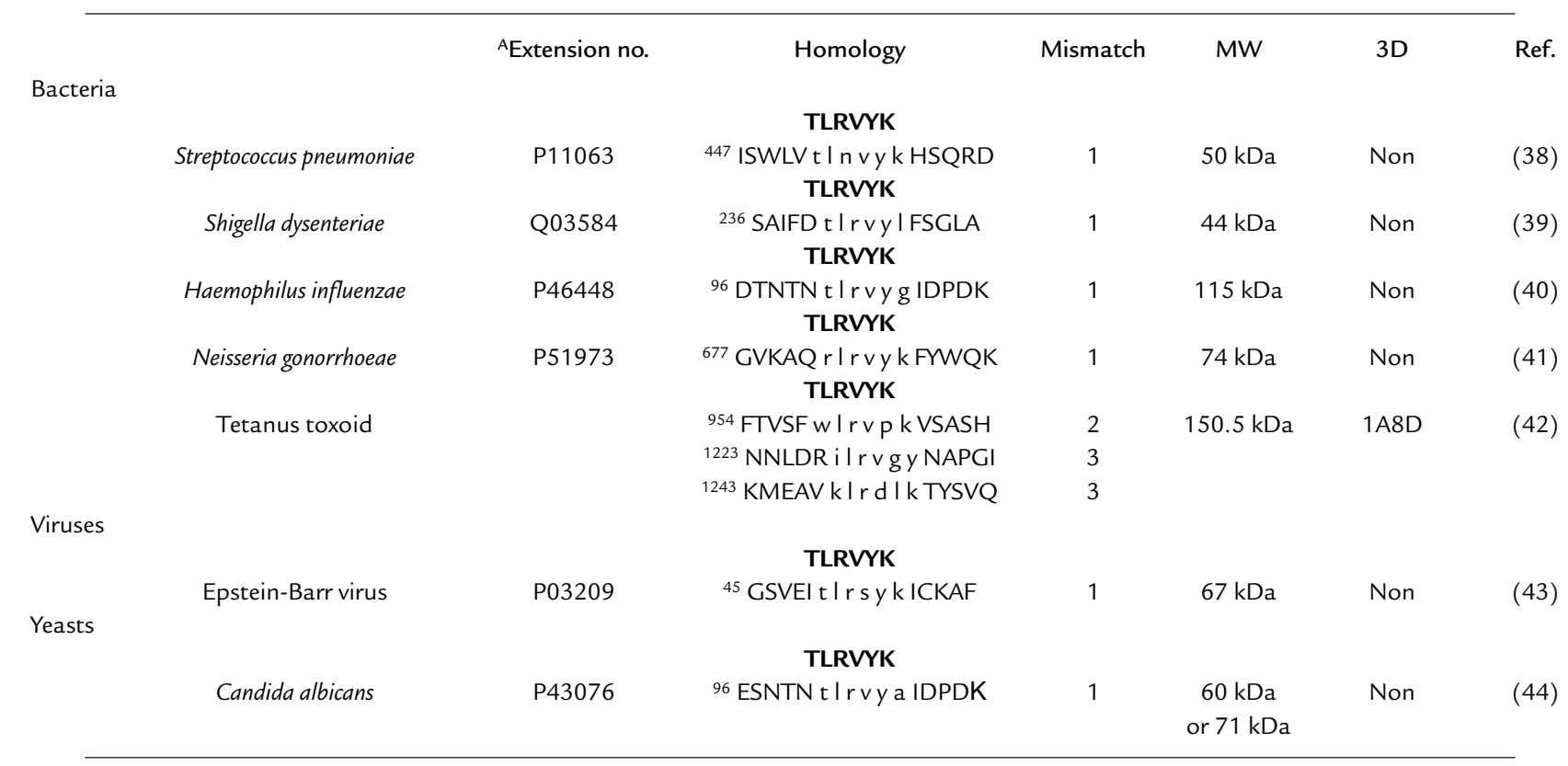

AExtension number in the Swiss database. 3D, three-dimensional. 
Table 2

Autoantibodies in the sera of mice immunized with bacteria/yeast homologous to the TLRVYK peptides ${ }^{\mathrm{A}}$

\begin{tabular}{|c|c|c|c|c|}
\hline Pathogen & Autoantibodies to & $\begin{array}{l}\text { Direct binding } \\
\text { (OD } 405 \mathrm{~nm} \text { ) }\end{array}$ & Ab levels & $P$ value $^{\mathrm{B}}$ \\
\hline Streptococcus & Cardiolipine & $0.742 \pm 0.085$ & & $P<0.006$ \\
\hline \multirow[t]{5}{*}{ pneumoniae } & $\beta 2 G P I$ & $0.393 \pm 0.094$ & $4.5 \mu \mathrm{g} / \mathrm{ml}$ & $P<0.01$ \\
\hline & CATLRVYKGG & $0.301 \pm 0.063$ & $3.3 \mu \mathrm{g} / \mathrm{ml}$ & $P<0.05$ \\
\hline & Scrambled peptide & $0.157 \pm 0.049$ & & \\
\hline & Phosphatidylcholine & $0.512 \pm 0.112$ & & $P<0.004$ \\
\hline & dsDNA & $0.074 \pm 0.082$ & & \\
\hline Shigella & Cardiolipine & $0.276 \pm 0.115$ & & $P<0.01$ \\
\hline \multirow{5}{*}{ dysenteriae } & $\beta 2 G P I$ & $0.227 \pm 0.108$ & $5.3 \mu \mathrm{g} / \mathrm{ml}$ & $P<0.01$ \\
\hline & CATLRVYKGG & $0.289 \pm 0.061$ & $3.9 \mu \mathrm{g} / \mathrm{ml}$ & $P>0.05$ \\
\hline & Scrambled peptide & $0.187 \pm 0.042$ & & \\
\hline & Phosphatidylcholine & $0.397 \pm 0.082$ & & $P<0.01$ \\
\hline & dsDNA & $0.099 \pm 0.081$ & & \\
\hline Haemophilus & Cardiolipine & $0.756 \pm 0.111$ & & $P<0.008$ \\
\hline \multirow[t]{5}{*}{ influenzae } & $\beta 2 \mathrm{GPI}$ & $0.841 \pm 0.099$ & $14.2 \mu \mathrm{g} / \mathrm{ml}$ & $P<0.001$ \\
\hline & CATLRVYKGG & $0.725 \pm 0.087$ & $17.1 \mu \mathrm{g} / \mathrm{ml}$ & $P<0.001$ \\
\hline & Scrambled peptide & $0.071 \pm 0.062$ & & \\
\hline & Phosphatidylcholine & $0.394 \pm 0.094$ & & $P<0.05$ \\
\hline & dsDNA & $0.121 \pm 0.079$ & & \\
\hline Neisseria & Cardiolipine & $0.702 \pm 0.098$ & & $P<0.008$ \\
\hline \multirow[t]{5}{*}{ gonorrhoeae } & $\beta 2 G P I$ & $0.594 \pm 0.099$ & $10.8 \mu \mathrm{g} / \mathrm{ml}$ & $P<0.01$ \\
\hline & CATLRVYKGG & $0.587 \pm 0.085$ & $12.4 \mu \mathrm{g} / \mathrm{ml}$ & $P<0.01$ \\
\hline & Scrambled peptide & $0.063 \pm 0.057$ & & \\
\hline & Phosphatidylcholine & $0.204 \pm 0.068$ & & $P>0.05$ \\
\hline & dsDNA & $0.119 \pm 0.089$ & & \\
\hline & Cardiolipine & $0.704 \pm 0.105$ & & $P<0.03$ \\
\hline \multirow{5}{*}{ albicans } & $\beta 2 G P I$ & $0.603 \pm 0.073$ & & $P<0.02$ \\
\hline & CATLRVYKGG & $0.378 \pm 0.092$ & $2.7 \mu \mathrm{g} / \mathrm{ml}$ & $P<0.05$ \\
\hline & Scrambled peptide & $0.117 \pm 0.045$ & $1.3 \mu \mathrm{g} / \mathrm{ml}$ & \\
\hline & Phosphatidylcholine & $0.379 \pm 0.122$ & & $P<0.05$ \\
\hline & dsDNA & $0.111 \pm 0.061$ & & \\
\hline Klebsiella & Cardiolipine & $0.203 \pm 0.068$ & & $P>0.05$ \\
\hline \multirow[t]{5}{*}{ pneumoniae } & $\beta 2 \mathrm{GPI}$ & $0.081 \pm 0.055$ & $0.07 \mu \mathrm{g} / \mathrm{ml}$ & $P>0.05$ \\
\hline & CATLRVYKGG & $0.063 \pm 0.041$ & $0.06 \mu \mathrm{g} / \mathrm{ml}$ & $P>0.05$ \\
\hline & Scrambled peptide & $0.071 \pm 0.052$ & & \\
\hline & Phosphatidylcholine & $0.082 \pm 0.029$ & & \\
\hline & dsDNA & $0.095 \pm 0.043$ & & \\
\hline Tetanus & Cardiolipine & $0.756 \pm 0.119$ & & $P<0.004$ \\
\hline \multirow[t]{5}{*}{ toxoid } & $\beta 2 G P I$ & $0.899 \pm 0.097$ & $14 \mu \mathrm{g} / \mathrm{ml}$ & $P<0.001$ \\
\hline & CATLRVYKGG & $0.674 \pm 0.111$ & $12.2 \mu \mathrm{g} / \mathrm{ml}$ & $P<0.006$ \\
\hline & Scrambled peptide & $0.083 \pm 0.073$ & & \\
\hline & Phosphatidylcholine & $0.237 \pm 0.095$ & & $P<0.05$ \\
\hline & dsDNA & $0.072 \pm 0.026$ & & \\
\hline
\end{tabular}

${ }^{A}$ Mean \pm SD OD at $405 \mathrm{~nm}$; sera dilution 1:200. ${ }^{\mathrm{B}} P$ values for anti-cardiolipin, anti- $\beta 2 \mathrm{GPI}$, and anti-CATLRVYKGG Ab's were calculated compared with anti-scrambled peptide Ab's. $P$ values for antiphosphatidylcholine Ab's were calculated compared with anti-dsDNA Ab's.

for passive infusion into naive mice. The affinity-purified anti- $\beta 2 \mathrm{GPI} A b$ 's were infused intravenously into $\mathrm{BALB} / \mathrm{c}$ mice $(40 \mu \mathrm{g})$ at day 0 of pregnancy. A control group of mice was infused with an irrelevant mouse IgG. APS clinical parameters (percentage of fetal resorptions, thrombocytopenia, and prolonged activated partial thromboplastin time [aPTT]) were evaluated in the infused mice on day 15 of pregnancy. Platelet counts from individual blood samples were quantified in diluted blood using a single optical cytometer (Coulter Counter HC Plus Cell Control; Counter Electronics Ltd., Basingstoke, United Kingdom). The presence of lupus anticoagulants was evaluated by the prolongation of aPTT in a mixing test (26), adding 1 vol of plasma from whole blood mixed with sodium citrate 0.123 $\mathrm{mol} / \mathrm{l}$ in a 9:1 ratio to $1 \mathrm{vol}$ of cephalin and incubating for 2 minutes at $37^{\circ} \mathrm{C}$. Another volume of $0.02 \mathrm{M} \mathrm{CL}$ was added, and the clotting time was recorded in seconds. Evaluation of pregnancy outcome was performed as follows: the vaginal plugs, indicating mating, were recorded and regarded as day 0 of pregnancy. The mice were sacrificed on day 15 of pregnancy. The percentage index of resorption of embryos in utero was calculated as follows: $\% R=R /(R+A)$; the number of resorbed $(\mathrm{R})$ fetuses divided by resorbed and alive (A) fetuses (25).

\section{Results}

The TLRVYK hexapeptide that reacted specifically with the H-3 anti- $\beta 2$ GPI mAb's (25) was screened using the Swiss protein database. A homology was found with different microbial pathogens (Table 2). Following immunization, all mice developed significant levels of aCL Ab's (Table 1). Elevated levels of mouse anti- $\beta 2$ GPI and antipeptide (TLRVYK) Ab's were observed, the highest being detected in those mice immunized with $H$. influenzae, $N$. gonorrhoeae, or tetanus toxoid (Table 2). The mouse autoantibodies bound $\beta 2$ GPI differentially in a dose-dependent manner (Figure 1). The group of mice immunized with a peptide-unrelated gram-negative bacteria (K. pneumoniae), as well as E. coli and $P$. mirabilis (data not shown), had undetectable levels of aCL Ab's as well as anti- $\beta 2$ GPI Ab's. No evidence for thrombocytopenia or prolongation of aPTT was observed in the mice actively immunized with microbial particles. Mouse antipeptide (TLRVYK) Ab's, originated from sera of mice immunized with microbial and tetanus toxoid particles, were affinity purified on a peptide column and characterized. Maximal affinity of antipeptide $A b$ 's were determined in the sera derived from mice immunized with $H$. influenzae, $N$. gonorrboeae, or tetanus toxoid to the peptide and are presented in Figure 2, whereas antipeptide Ab's derived from mice 


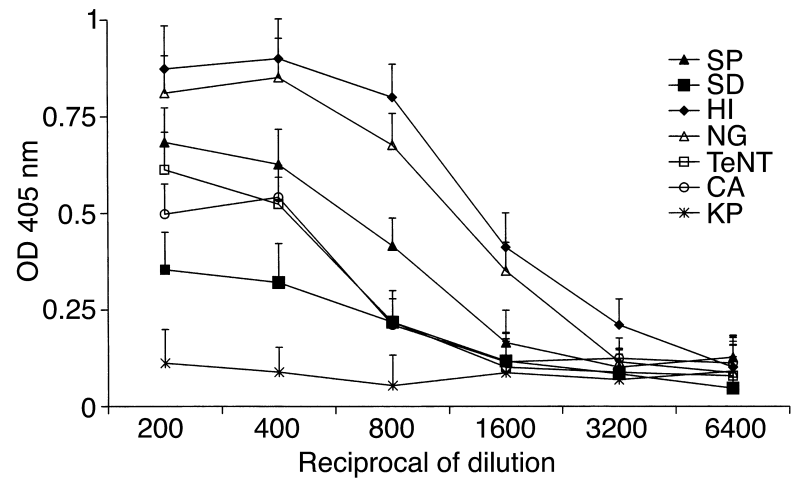

Figure 1

Anti- $\beta 2$ GPI binding properties of mouse sera derived from different bacteria/yeast-immunized mice. Sera derived from mice immunized with $H$. influenzae $(\mathrm{HI}), N$. gonorrhoeae (NG), tetanus toxoid (TeNT), Streptoccocus pneumoniae (SP), Shigella dysenteriae (SD), C. albicans (CA), or Klebsiella pneumoniae (KP) were assayed at different dilutions for binding to $\beta 2 \mathrm{GPI}$ by ELISA. Data are presented as OD at $405 \mathrm{~nm}$ (mean \pm SD of three different experiments).

immunized with C. albicans, Streptococcus pneumoniae, and Shigella dysenteriae had low affinity binding to the peptide (Figure 2).

The specificity of recognition of microbial particle or tetanus toxoid by the affinity-purified mouse antipeptide (TLRVYK) Ab's was studied by competition assays (Figure 3) and immunoblot analysis (Figure 4). Highly significant inhibition of TLRVYK peptide binding by mouse antipeptide (TLRVYK) Ab's derived from $H$. influenzae-, N. gonorrhoeae-, or tetanus toxoid-immunized mice, compared with scrambled peptide as a control, is presented in Figure 3 ( $77 \%$ to $89 \%$ vs. 5\% to $9 \%$ at $12.5 \mu \mathrm{M}$ of competitor; $P<0.001$ for all three). Antipeptide Ab's originated from C. albicans, Shigella dysenteriae, and Streptococcus pneumoniae showed no significant competition at concentration of $12.5 \mu \mathrm{M}$ of TLRVYK peptide $(P>0.05)$, although at higher concentrations of competitor $(100 \mu \mathrm{M})$ some degree of competition could be observed, yet was not significant (38\% to $47 \%, P>0.05$, compared with $27 \%$ to $39 \%$ inhibition by the scrambled peptide at the same concentration, data not shown). The specificity of recognition of H. influenzae, N. gonorrboeae, or tetanus toxoid particles, by the corresponding affinity-purified antipeptide $\mathrm{Ab}$ 's, was confirmed by immunoblot studies (Figure 4). Sera from mice immunized with $H$. influenzae, $N$. gonorrboeae, or tetanus toxoid showed wide binding to different molecular-weight structures and low binding to the relevant protein (lanes A, C, and E, respectively; see Table 1 for details of specific microbe-associated proteins). Affinity-purified antipeptide Ab's from the same origin showed specific binding (e.g., antipeptide Ab's from $N$. gonorrhoeae-immunized mice recognized the 74-kDa range (lane $\mathrm{B}$ ), antipeptide $\mathrm{Ab}$ 's from $H$. influenzae-immunized mice recognized the $115-\mathrm{kDa}$ range (lane D), and antipeptide Ab's from tetanus toxoid-immunized mice recognized the $150-\mathrm{kDa}$ range (lane F); see Table 1 for references of each microbe-specific protein). No recognition of a specific structure by antipeptide Ab's derived from C. albicans-, Shigella disenteriae-, or Streptococcus pneumoniae-immunized mice was detected (data not shown).

Naive BALB $/ \mathrm{c}$ mice were infused with affinity-purified mouse antipeptide Ab's originated from mice immunized with the various microbial particles. Mice that were infused with antipeptide Ab's derived from mice immunized with $H$. influenzae, $N$. gonorrboeae, or with tetanus toxoid developed the clinical manifestations of experimental APS. These mice had an elevated percentage of fetal loss $(17 \% \pm 2 \%$ to $48 \% \pm 3 \%$ vs. $4 \% \pm 1 \%$ to $7 \% \pm 2 \% ; P<0.001)$, thrombocytopenia (497 \pm 98 to $603 \pm 142$ vs. $918 \pm 216$ to $1,012 \pm 214$ cells $/ \mathrm{mm}^{3} \times 10^{3}$; $P<0.01)$, and prolonged aPTT ( $48 \pm 6$ to $69 \pm 4$ seconds vs. $22 \pm 2$ to $27 \pm 4$ seconds; $P<0.01)$, similar to the positive control group of mice immunize with the pathogenic H-3 anti-ß2GPI mAb (26) (Table 3).

Pathological findings. Female mice immunized with tetanus toxoid, Shigella dysenteriae, Streptococcus pneumoniae, H. influenzae, C. albicans, or N. gonorrboeae, as well as female mice that received antipeptide Ab's from mice immunized with the same microbial pathogens, were studied for the presence of pathological findings in the lungs, brain, heart, kidneys, or liver. Each group consisted of five mice. In addition, male mice that received antipeptide $\mathrm{Ab}$ 's from mice immunized with the same microbial pathogens were studied as well. No thrombosis was detected in all the groups of mice. No pathology was found in the brain, lungs, heart, kidneys, or the liver of the mice that were passively transferred with antipeptide Ab's, either females or males. Several nonspecific pathological findings in some organ systems were observed in mice immunized with the bacterial extracts. These included peribronchial mononuclear infiltration and focal glomerulonephritis in mice immunized with tetanus toxoid, periportal

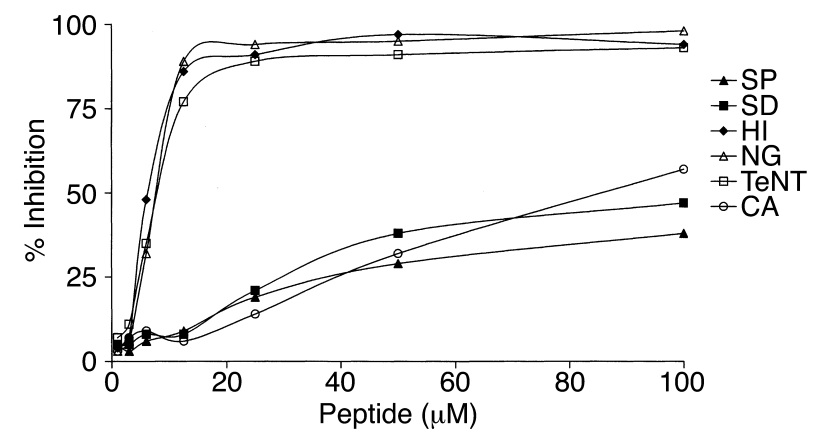

\section{Figure 2}

Affinity determination of mouse affinity-purified Ab's to the peptide. Using several molar concentrations of $\mathrm{NH}_{4} \mathrm{SCN}$, the percentage of affinity-purified antipeptide Ab's binding to the peptide was determined by ELISA. The antipeptide Ab's were derived from mice immunized with $H$. influenzae (HI), N. gonorrhoeae (NG), tetanus toxoid (TeNT), Streptoccocus pneumoniae (SP), Shigella dysenteriae (SD), or C. albicans (CA) at $A b$ concentrations of $20 \mu \mathrm{g} / \mathrm{ml}$. Data are presented as percentage of binding in three separate experiments. 


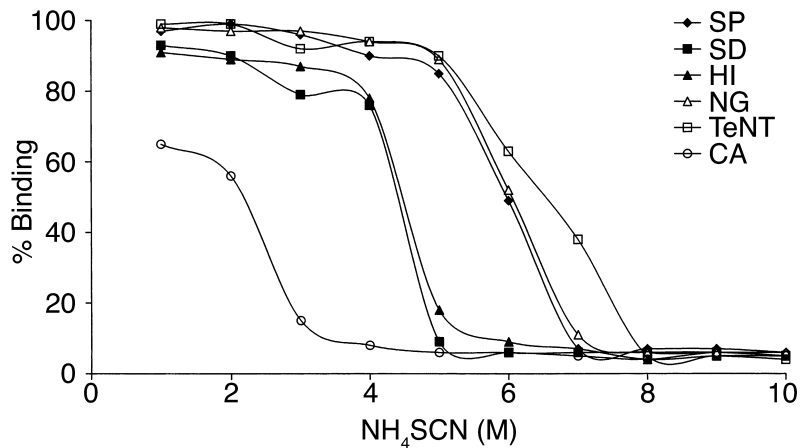

Figure 3

Inhibition of binding of affinity-purified mouse antipeptide $A b$ to the corresponding synthetic peptide. Antipeptide Ab's, affinity purified from mice immunized with $H$. influenzae $(\mathrm{HI}), N$. gonorrhoeae $(\mathrm{NG})$, tetanus toxoid (TeNT), Streptoccocus pneumoniae (SP), Shigella dysenteriae (SD), or C. albicans (CA) competed for binding to the relevant synthetic peptide by the peptide CATLRVYKGG. Scrambled peptide (TGVGKALYCR) was used as a control.

mononuclear and polymorphonuclear infiltration in the liver parenchyma of mice immunized with $N$. gonorrhoeae, and focal bronchial pneumonia in mice immunized with Streptococcus pneumoniae.

\section{Discussion}

In the present study we show, we believe for the first time, that a spectrum of experimental APS can be induced by immunization with certain microbial pathogens that share epitope homology with the $\beta 2 \mathrm{GPI}$ molecule. Pathogenic anti- $\beta 2$ GPI Ab's directed against the TLRVYK epitope were formed in mice that were immunized with $H$. influenzae or $N$. gonorrhoeae that exhibit the TLRVYK sequence. The same anti- $\beta 2$ GPI Ab's were generated in mice immunized with tetanus toxoid. The elution of tetanus-immunized mice sera on the IgG TLRVYK peptide column indicates that tetanus toxoid, while not presenting the linear TLRVYK sequence, conformationally mimics it, i.e., a mimotope. The formed anti- $\beta 2$ GPI $A b$ 's proved pathogenic and capable of inducing the clinical picture of experimental APS, manifested by high percentage of fetal loss, thrombocytopenia, and prolonged aPTT. Previously, aPLs have been documented in a large number of infectious diseases, including viral, bacterial, spirochetal, and parasitic infections (8). Several groups classified aPLs as either "pathogenic" Ab's (autoimmune type), whose binding to their respective aPL is enhanced by the $\beta 2$ GPI cofactor, or the "infectious" type (i.e., the nonthrombogenic aPLs), which bind cardiolipin without requiring $\beta 2 \mathrm{GPI}(2,28,29)$. This classification, however, is challenged by other reports. Hojnik et al. (30) found increased levels of anti- $\beta 2$ GPI Ab's in a significant proportion of leprotic patients, an observation that was confirmed by other investigators who indicated that these $\beta 2 \mathrm{GPI}$-dependent aPLs were associated with thrombosis in leprosy (31). In another study, parvovirus B19-associated aCL Ab's were shown to be $\beta 2 \mathrm{GPI}$ dependent and behaved in a fashion similar to the autoimmune aPLs (32). Furthermore, some cases of viral hepatitis $\mathrm{C}$-associated aPLs have been reported to be complicated with thrombosis (33). Although the incidence and clinical significance of $\beta 2 \mathrm{GPI}$-dependent $\mathrm{aCL} A b$ 's and anti- $\beta 2$ GPI Ab's in infectious diseases remains largely unknown, it is possible that infections might trigger the development of pathogenic anti$\beta 2$ GPI Ab's, conceivably by molecular mimicry, and thus promote the development of APS, particularly in predisposed individuals. Recently, employing the shotgun phage display technique, Zhang et al. (34) identified a Staphylococcus aureus protein, Sbi, which binds $\beta 2 \mathrm{GPI}$ and serves as target molecule for IgG binding. It was also shown that protein Sbi, and thus the $\beta 2 \mathrm{GPI}-$ binding potential, is expressed on the staphylococcal cell surface at levels varying between strains (34). Further support for epitope mimicry as possible mechanism for APS development comes from a recent study of Gharavi et al. (35). Synthetic peptides that share structural similarity with the putative phospholipidbinding region of the $\beta 2 \mathrm{GPI}$ molecule, and share high homology with cytomegalovirus, were able to induce

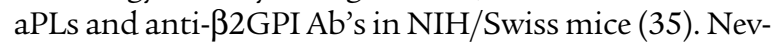
ertheless, the emergence of mouse autoantibodies was not accompanied by clinical features of APS; i.e., the anti- $\beta 2$ GPI $A b$ 's were nonpathogenic. In contrast to these nonpathogenic anti- $\beta 2$ GPI Ab's directed against the putative phospholipid-binding region of the $\beta 2 \mathrm{GPI}$ molecule, i.e., an epitope located in the fifth domain of the $\beta 2 \mathrm{GPI}$ molecule, the pathogenic anti- $\beta 2 \mathrm{GPI}$ in our study is directed against the third domain-located TLRVYK epitope (36). Recently, the TLRVYK peptide was shown by us as the target epitope for the pathogenic H-3 mAb (25). Our current data demonstrate that this target molecule, also mimicked by several microbial pathogens, is responsible for a generation of pathogenic anti- $\beta 2$ GPI $A b$ 's as shown by the in vivo studies. Further studies, conceivably employing $\beta 2$ GPI-knockout mice, can contribute in further clarification of in vivo mechanisms involved in the effect of the pathogenic

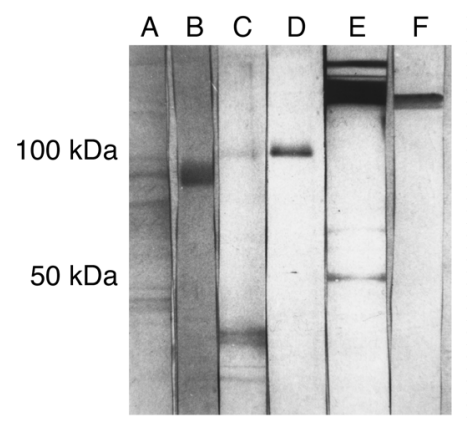

\section{Figure 4}

Binding of sera or affinity-purified antipeptide Ab's to bacterial extracts or to tetanus toxoid. Binding of sera derived from mice immunized with $H$. influenzae, $N$. gonorrhoeae, or tetanus toxoid at sera dilution of 1:20, are described in lanes A, C, and E, respectively. Antipeptide Ab's affinity purified from the same immunized mice are described in lanes $B, D$, and $F$, respectively. 

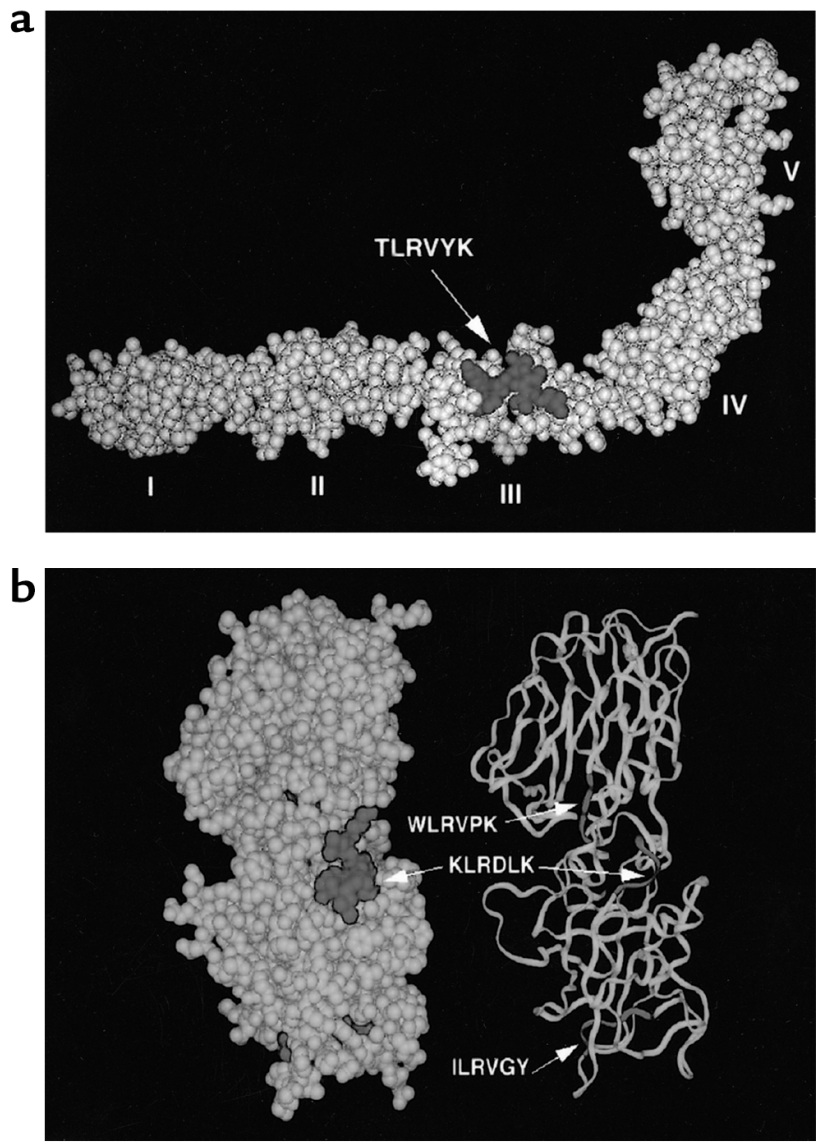

anti- $\beta 2$ GPI Ab's (37). Since the mouse anti-TLRVYK $A b$ 's are directed against an epitope located on the third domain of the 32 GPI molecule, deficiency of this molecule may block the induction of the disease.

Not all the homologous microbial pathogens in our study could provoke in vivo generation of pathogenic anti- $\beta 2$ GPI Ab's capable of inducing experimental APS (Streptococcus pneumoniae, Shigella dysenteriae, and C. albicans), despite development of anti- $\beta 2$ GPI. Part of the difference between the pathogenic potential of the bacteria-induced anti- $\beta 2$ GPI Ab's may be explained by the

\section{Figure 5}

Three-dimensional Ribbon diagram of the $\beta 2 \mathrm{GPI}$ (a) and partial structure of tetanus toxoid (b). The peptide TLRVYK and the relevant mimicry on a tetanus toxoid partial molecule are emphasized in dark gray.

variability in recognition of the $\beta 2$ GPI molecule by the Ab's. Characterization of the mouse antipeptide $A b$ 's derived from the different groups of bacteria/yeast-immunized mice, using competition assays and affinity studies to the peptide, revealed differences in the binding to $\beta 2 \mathrm{GPI}$ or in the competition with the relevant peptide (Figure 2 and Figure 3, respectively). The apparent diversity of the antipeptide Ab's may be a result of a partial recognition of the amino acids of the peptide by the different populations of the affinity-purified immunoglobulins, which might reduce the capability of recognition. Indeed, it is evident from the immunoblot analysis that while antipeptide Ab's originating from mice immunized with $H$. influenzae, N. gonorrboeae, or tetanus toxoid (Figure 5) recognized the relevant peptides associated with each bacteria, antipeptide $\mathrm{Ab}$ 's induced by Streptococcus pneumoniae, Shigella dysenteriae, or C. albicans showed no specific recognition (Figure 4, Table 1). Further studies, employing synthetic peptides in which one or more amino acids are replaced, will help to identify specific amino acids that contribute to the full recognition of TLRVYK by antipeptide $\mathrm{Ab}$ 's from the different sources.

Following active immunization with various microbial particles, anti- $\beta 2$ GPI Ab's were produced, yet no APS manifestations could be observed in the immunized mice. Nonetheless, passive infusion of the affinity-purified anti-32GPI from the later mice induced experimental APS in another set of naive mice. Several factors probably accounted for the reduced APS pathogenicity of the bacterial-extracts immunization. Not all the antipeptide $\mathrm{Ab}$ 's induced by the bacterial immunization were pathogenic, as evident by the results of the antipeptide infusion into the naive mice. Furthermore, these Ab's were produced in low titers (Table 2). The pathogenic potential of the Ab's was probably further reduced by the generation

Table 3

APS manifestations in mice infused with anti- $\beta 2$ GPI autoantibodies originated from mice immunized with specific bacteria/yeast

Origin of anti- $\beta 2 \mathrm{GPI}$ from mice immunized with

$\begin{array}{lcccccccc} & \mathrm{H}-3 \mathrm{mAb} & \mathrm{SP} & \mathrm{SD} & \mathrm{HI} & \mathrm{NG} & \mathrm{CA} & \text { KP } & \text { TeNT } \\ & n=15 & n=7 & n=7 & n=12 & n=10 & n=8 & n=12 & n=14 \\ \text { Platelet count } & 438 \pm 103 & 918 \pm 216 & 1,012 \pm 214 & 527 \pm 126 & 603 \pm 142 & 994 \pm 221 & 998 \pm 112 & 497 \pm 98 \\ \left.\text { (cells } / \mathrm{mm}^{3} \times 10^{3}\right) & P<0.02 & P>0.05 & P>0.05 & P<0.02 & P<0.04 & P>0.05 & P>0.05 & P<0.02 \\ \text { aPTT }(\mathrm{sec}) & 61 \pm 5 & 27 \pm 4 & 23 \pm 3 & 59 \pm 5 & 48 \pm 6 & 22 \pm 2 & 23 \pm 3 & 69 \pm 4 \\ & P<0.03 & P>0.05 & P>0.05 & & & P>0.05 & P>0.05 & 4 \% \pm 1 \% \\ \text { Fetal resorption } & 34 \% \pm 4 \% & 6 \% \pm 1 \% & 4 \% \pm 2 \% & 28 \% \pm 3 \% & 17 \% \pm 2 \% & 7 \% \pm 2 \% & 48 \% \pm 3 \% \\ & P<0.03 & P>0.05 & P>0.05 & P<0.05 & P>0.05 & P>0.05 & P>0.05 & P<0.02\end{array}$

K. pneumoniae was used as a negative control of TLRVYK-unrelated bacteria, and $\mathrm{H}-3 \mathrm{mAb}$ served as a positive control. BALB/c mice were infused with $40 \mu \mathrm{g}$ affinity-purified anti- $\beta 2 \mathrm{GPI}$ Ab's from mice immunized with bacteria/yeast intravenously at day 0 of pregnancy (determined by the presence of vaginal plugs). Mice infused with an irrelevant mouse lgG showed $7 \% \pm 2 \%$ of fetal resorption, platelet count of $1,037 \pm 217$ cells $/ \mathrm{mm}^{3} \times 10^{3}$, and aPTT of $23 \pm 1$ second, and served as control. SP, Streptococcus pneumoniae; SD, Shigella dysenteriae; HI, H. influenzae; NG, N. gonorrhoeae; CA, C. albicans; TeNT, tetanus toxoid; KP, K. pneumoniae. 
of a wide panel of irrelevant $A b$ 's associated with a multitude of bacterial antigens exposure, deviating the immune response into "irrelevant" pathways, as exemplified by the multiple nonspecific pathological findings in various organ systems in the immunized mice.

In conclusion, our study supports a mechanism of molecular mimicry in induction of APS, demonstrating that $\beta 2 \mathrm{GPI}$-structure homologous bacteria are able to induce pathogenic anti- $\beta 2$ GPI Ab's, and when purified and concentrated can lead to APS manifestations. Our results also identify the third domain-located TLRVYK epitope as one of the epitopes responsible for pathogenic anti-32GPI generation.

\section{Acknowledgments}

The work was supported by The Israel Science Foundation funded by the Israel Academy of Sciences and Humanities (736/96). We thank Miriam Eisenstein from the Unit of Chemical Services, The Weizmann Institute of Science, Rehovot, Israel, for her contribution to the molecular modeling of the study.

1. Hughes, G.R., Harris, N.N., and Gharavi, A.E. 1986. The anticardiolipin syndrome. J. Rheumatol. 13:486-489.

2. McNeil, H.P., Simpson, R.J., Chesterman, C.N., and Krilis, S.A. 1990 Anti-phospholipid antibodies are directed against a complex antigen that includes a lipid-binding inhibitor of coagulation: beta 2-glycoprotein I (apolipoprotein H). Proc. Natl. Acad. Sci. USA. 87:4120-4124.

3. Matsuura, E., et al. 1992. Heterogeneity of anticardiolipin antibodies defined by the anticardiolipin cofactor. J. Immunol. 148:3885-3891.

4. Shoenfeld, Y., Gharavi, A., and Koike, T. 1998. 32 GP-I in the antiphospholipid (Hughes') syndrome - from a cofactor to an autoantigen - from induction to prevention of antiphospholipid syndrome. Lupus. 7:503-506.

5. Gharavi, A.E., Sammaritano, L.R., Wen, J., and Elkon, K.B. 1992. Induction of antiphospholipid autoantibodies by immunization with beta 2 glycoprotein I (apolipoprotein H). J. Clin. Invest. 90:1105-1109.

6. Blank, M., et al. 1994. Immunization with anticardiolipin cofactor (beta2-glycoprotein I) induces experimental antiphospholipid syndrome in naive mice. J. Autoimmun. 7:441-455.

7. George, J., et al. 1998. Differential effects of anti-beta2-glycoprotein I antibodies on endothelial cells and on the manifestations of experimental antiphospholipid syndrome. Circulation. 97:900-906.

8. Loizou, S.A., Walport, M.J., and Davies, K.A. 1996. The antiphospholipid syndrome in infectious diseases. In The antiphospholipid syndrome. R. Asherson, R. Cervera, J.C. Piette, and Y. Shoenfeld, editors. CRC Press Inc. Andover, United Kingdom. 267-284.

9. Puri, V., Bookman, A., Yeo, E., Cameron, R., and Heathcote, E.J. 1999. Antiphospholipid antibody syndrome associated with hepatitis $\mathrm{C}$ infection. J. Rheumatol. 26:509-510.

10. Yanez, A., et al. 1999. Mycoplasma penetrans bacteremia and primary antiphospholipid syndrome. Emerg. Infect. Dis. 5:164-167.

11. Hayem, G., et al. 1999. Systemic lupus erythematosus-associated catastrophic antiphospholipid syndrome occurring after typhoid fever: a possible role of Salmonella lipopolysaccharide in the occurrence of diffuse vasculopathy-coagulopathy. Arthritis Rheum. 42:1056-1061.

12. Shoenfeld, Y., Blank, M., and Krause, I. 2000. The relationship of antiphospholipid antibodies to infections-do they bind to infecting agents or may they even be induced by them. Clin. Exp. Rheumatol. 18:431-432.

13. Asherson, R.A., et al. 2001. Catastrophic antiphospholipid syndrome: clues to the pathogenesis from a series of 80 patients. Medicine (Baltimore). 80:355-377.

14. Oldstone, M.B. 1998. Molecular mimicry and immune-mediated diseases. FASEB J. 12:1255-1265

15. Karlsen, A.E., and Dyrberg, T. 1998. Molecular mimicry between nonself, modified self and self in autoimmunity. Semin. Immunol. 10:25-34

16. Albert, L.J., and Inman, R.D. 1999. Molecular mimicry and autoimmunity. N. Engl. J. Med. 341:2068-2074.

17. Fujinami, R.S., and Oldstone, M.B. 1985. Amino acid homology between the encephalitogenic site of myelin basic protein and virus: mechanism for autoimmunity. Science. 230:1043-1045.

18. Singh, V.K., et al. 1990. Molecular mimicry between a uveitopathogenic site of S-antigen and viral peptides. Induction of experimental autoimmune uveitis in Lewis rats. J. Immunol. 144:1282-1287.
19. Gauntt, C.J., et al. 1995. Coxsackievirus-induced chronic myocarditis in murine models. Eur. Heart J. 16(Suppl.):56-58.

20. Mokhtarian, F., Zhang, Z., Shi, Y., Gonzales, E., and Sobel, R.A. 1999. Molecular mimicry between a viral peptide and a myelin oligodendrocyte glycoprotein peptide induces autoimmune demyelinating disease in mice. J. Neuroimmunol. 95:43-54.

21. Zhao, Z.S., Granucci, F., Yeh, L., Schaffer, P.A., and Cantor, H. 1998. Molecular mimicry by herpes simplex virus-type 1: autoimmune disease after viral infection. Science. 279:1344-1347.

22. Grogan, J.L., et al. 1999. Cross-reactivity of myelin basic protein-specific T cells with multiple microbial peptides: experimental autoimmune encephalomyelitis induction in TCR transgenic mice. J. Immunol. 163:3764-3770

23. Gautam, A.M., Liblau, R., Chelvanayagam, G., Steinman, L., and Boston, T. 1998. A viral peptide with limited homology to a self peptide can induce clinical signs of experimental autoimmune encephalomyelitis. J. Immunol. 161:60-64.

24. Wucherpfennig, K.W. 2001. Mechanisms for the induction of autoimmunity by infectious agents. J. Clin. Invest. 108:1097-1104. DOI:10.1172/JCI200114235.

25. Blank, M., et al. 1999. Prevention of experimental antiphospholipid syndrome and endothelial cell activation by synthetic peptides. Proc. Natl. Acad. Sci. USA. 96:5164-5168.

26. Bakimer, R., et al. 1992. Induction of primary antiphospholipid syndrome in mice by immunization with a human monoclonal anticardiolipin antibody (H-3). J. Clin. Invest. 89:1558-1563.

27. Sutjita, M., Hohmann, A., Comacchio, R., Boey, M.L., and Bradley, J. 1989. A common anti-cardiolipin antibody idiotype in autoimmune disease: identification using a mouse monoclonal antibody directed against a naturally-occurring anti-phospholipid antibody. Clin. Exp. Immunol. 75:211-216.

28. Galli, M., et al. 1990. Anticardiolipin antibodies (ACA) directed not to cardiolipin but to a plasma protein cofactor. Lancet. 335:1544-1547.

29. Matsuura, E., Igarashi, Y., Fujimoto, M., Ichikawa, K., and Koike, T. 1990. Anticardiolipin cofactor(s) and differential diagnosis of autoimmune disease. Lancet. 336:177-178.

30. Hojnik, M., et al. 1994. Anticardiolipin antibodies in infections are heterogenous in their dependency on beta 2-glycoprotein I: analysis of anticardiolipin antibodies in leprosy. Lupus. 3:515-521.

31. Fiallo, P., Nunzi, E., and Cardo, P.P. 1998. Beta2-glycoprotein I-dependent anticardiolipin antibodies as risk factor for reactions in borderline leprosy patients. Int. J. Lepr. Other Mycobact. Dis. 66:387-388.

32. Loizou, S., Cazabon, J.K., Walport, M.J., Tait, D., and So, A.K. 1997. Similarities of specificity and cofactor dependence in serum antiphospholipid antibodies from patients with human parvovirus B19 infection and from those with systemic lupus erythematosus. Arthritis Rheum. 40:103-108.

33. Giordano, P., et al. 1998. Lupus anticoagulant, anticardiolipin antibodies and hepatitis $\mathrm{C}$ virus infection in thalassaemia. Br. J. Haematol. 102:903-906

34. Zhang, L., Jacobsson, K., Strom, K., Lindberg, M., and Frykberg, L. 1999. Staphylococcus aureus expresses a cell surface protein that binds both IgG and beta2-glycoprotein I. Microbiology. 145:177-183.

35. Gharavi, E.E., et al. 1999. Induction of antiphospholipid antibodies by immunization with synthetic viral and bacterial peptides. Lupus. 8:449-455.

36. Schwarzenbacher, R., et al. 1999. Crystal structure of human beta2-glycoprotein I: implications for phospholipid binding and the antiphospholipid syndrome. EMBOJ. 18:6228-6239.

37. Sheng, Y., et al. 2001. Impaired thrombin generation in beta 2-glycoprotein I null mice. J. Biol. Chem. 276:13817-13821.

38. Oskam, L., Hillenga, D.J., Venema, G., and Bron, S. 1991. The large bacillus plasmid pTB19 contains two integrated rolling-circle plasmids carrying mobilization functions. Plasmid. 26:30-39.

39. Sturm, S., Jann, B., Jann, K., Fortnagel, P., and Timmis, K.N. 1986. Genetic and biochemical analysis of Shigella dysenteriae $1 \mathrm{O}$ antigen polysaccharide biosynthesis in Escherichia coli K-12: structure and functions of the rfb gene cluster. Microb. Pathog. 1:307-324.

40. Fleischmann, R.D., et al. 1995. Whole-genome random sequencing and assembly of Haemophilus influenzae Rd. Science. 269:496-512.

41. Facius, D and Meyer, T.F. 1993. A novel determinant (comA) essential for natural transformation competence in Neisseria gonorrboede and the effect of a comA defect on pilin variation. Mol. Microbiol. 10:699-712.

42. Krieglstein, K.G., Henschen, A.H., Weller, U., and Habermann, E. 1991. Limited proteolysis of tetanus toxin. Relation to activity and identification of cleavage sites. Eur. J. Biochem. 202:41-51.

43. Baer, R., et al. 1984. DNA sequence and expression of the B95-8 EpsteinBarr virus genome. Nature. 310:207-211.

44. Saporito-Irwin, S.M., Birse, C.E., Sypherd, P.S., and Fonzi, W.A. 1995. PHR1, a pH-regulated gene of Candida albicans, is required for morphogenesis. Mol. Cell Biol. 15:601-613. 